\title{
Development of Android Applications as an Operating System Media for Learning Electronic Control Competencies in ClassXI students SMKN 2 Pengasih
}

\author{
Singgih Yuntoto \\ Electrical Engineering Education Study Program, Faculty of Engineering, \\ Universitas Negeri Yogyakarta
}

\begin{tabular}{r}
\hline ARTICLEINFO \\
\hline Article history: \\
Received June 9, 2021 \\
Revised July 20, 2021 \\
Accepted July 30, 2021
\end{tabular}

Keywords:

Android applications,; Learning media; Electronic control system.

\begin{abstract}
At this time the learning process by teachers rarely uses technology and learning media. Students have difficulty using learning media. The limitation of tools is an obstacle in accessing learning media. This research is a type of development research. The product development model adopts a software development model consisting of (1) software requirements analysis, (2) design, (3) code writing and (4) testing. Data collection techniques were carried out by observation, interviews and questionnaires. The testing phase is carried out with product validation by experts, testing on first users (teachers) and testing on end users (students). The data analysis technique used is descriptive analysis technique. The results of this study are: (1) the android application model for appropriate learning media on the competence of operating the electronic control system includes preparation, the subject matter of the operation of the electronic control system, and the evaluation model of choice questions; (2) test the functionality of the android application for appropriate learning media on the competence of operating an electronic control system including ease of navigation, application performance and ease of operation; (3) the feasibility of the android application for appropriate learning media on the competence of operating the electronic control system, based on the performance of the application it can run well. Based on the converted average assessment with a score range of $0-100$, the score from media experts was obtained with a score of 83.33 in the "very feasible" category, the assessment by material experts with a score of 71 .
\end{abstract}

This is an open access article under the CC BY-NC license.

\section{Corresponding Author:}

Singgih Yuntoto,

Electrical Engineering Education Study Program, Faculty of Engineering,

Universitas Negeri Yogyakarta

E-mail: singgihyuntoto@gmail.com

\section{INTRODUCTION}

The use of technology and media in learning can form a learning atmosphere in which students can actively participate. Learning media is a liaison between teachers and students, thanks to the media students are no longer limited by the boundaries of the classroom. Students can study in various places such as through the internet or their mobile phones. This is in accordance with what was conveyed by Sharon E. Smaldino and James D. Russell (2005:9).

The development of mobile device technology has become an alternative device that is cheaper than personal computers such as desktop computers or laptops. The existence of cheap devices can make it easier for students to access learning media. With these inexpensive devices, 
students from lower middle class can buy these devices. The use of mobile learning in schools is still small. UNESCO's annual report states that the use of mobile phones in schools is still considered taboo. In schools, the use of cell phones is still prohibited, so if a student uses a cellphone, it will be confiscated (Chimbelu, 2014).

The advantages of mobile learning can be used to overcome the limitations of the PC. The advantages of mobile devices include being easy to carry, being able to connect to the network anytime and anywhere, more flexible in accessing learning resources, close communication, students can be involved and active (Woodill, 2010:24) Ease and low prices are the main advantages.

Developing mobile-based learning media can increase student interest in the learning process. Android application development is supported by Google. Google itself provides software for developing applications, namely the Android SDK (Software Development Kit). This android SDK supports android development using Eclipse and ADT software. Google also provides a complete tutorial for creating android applications. One of the most popular mobile OS is android. Android dominates the market by $76.3 \%$, iOS $13.2 \%$, Windows Home $3.7 \%$, BB OS $2.9 \%$, Linux 0.8 , Symbian $0.2 \%$ and others $0.0 \%$, the survey was taken in the quarter third 2013 (IDC, 2014). From these data, it can be seen that the Android operating system has the largest number of users. Android is also an open source operating system so it is relatively easy to develop applications. Competence to operate an electronic control system is a competency that must be supported by theoretical and practical abilities. The lack of learning media makes it difficult for students to understand the theory. Lack of understanding in theory also has an impact on practical ability because they still do not understand the theory. The development of learning media is expected to overcome these problems. To reduce costs and ease of use, the mobile loan model was chosen. Mobile learning based on the Android operating system is easier to create and use, therefore the development of this application uses the Android operating system. Competence to operate an electronic control system is a competency that must be supported by theoretical and practical abilities.

The lack of learning media makes it difficult for students to understand the theory. Lack of understanding in theory also has an impact on practical ability because they still do not understand the theory. The development of learning media is expected to overcome these problems. To reduce costs and ease of use, the mobile loan model was chosen. Mobile learning based on the Android operating system is easier to create and use, therefore the development of this application uses the Android operating system. Competence to operate an electronic control system is a competency that must be supported by theoretical and practical abilities. The lack of learning media makes it difficult for students to understand the theory. Lack of understanding in theory also has an impact on practical ability because they still do not understand the theory. The development of learning media is expected to overcome these problems. To reduce costs and ease of use, the mobile loan model was chosen. Mobile learning based on the Android operating system is easier to create and use, therefore the development of this application uses the Android operating system. Lack of understanding in theory also has an impact on practical ability because they still do not understand the theory. The development of learning media is expected to overcome these problems. To reduce costs and ease of use, the mobile loan model was chosen. Mobile learning based on the Android operating system is easier to create and use, therefore the development of this application uses the Android operating system. Lack of understanding in theory also has an impact on practical ability because they still do not understand the theory. The development of learning media is expected to overcome these problems. To reduce costs and ease of use, the mobile loan model was chosen. Mobile learning based on the Android operating system is easier to create and use, therefore the development of this application uses the Android operating system.

\section{METHOD}

\section{Research methods}

This research method uses the software research method by Pressman (2001:29) which consists of 4 types of activities, namely: Software requirements analysis, Design, Code generation and Testing. With additional support activities such as project tracking and control, 
risk management, quality assurance, configuration management, technical review and others carried out throughout the whole process. The development model uses the Waterfall Model with processes ranging from Analysis to Testing that are carried out linearly. In this process, each main activity must be completed thoroughly before moving on to the next activity.

2. Data collection

Data were collected through interviews. Interviews were conducted to communicate with users and stakeholders. Interviews are intended to get an idea of the needs that are used to determine the application to be made.

3. The data obtained through the collected questionnaires were then analyzed with quantitative statistics. The results of the questionnaire were analyzed using the following criteria (Mardapi, 2004:117).

Table 1.

Category Four Scale

\begin{tabular}{cc}
\hline Score & Interpretation \\
\hline 4 & Very Worthy \\
3 & Worthy \\
2 & Not feasible \\
1 & Very unworthy \\
\hline
\end{tabular}

The score obtained is converted into a value on a scale of 4 which is described in Table 2.

Table 2.

Rating Category

\begin{tabular}{cc}
\hline Score interval & Category \\
\hline $\mathrm{X}>\mathrm{Mi}+1,5(\mathrm{SDi})$ & Very Worthy \\
$\mathrm{Mi}<\mathrm{X}<\mathrm{Mi}+1.5(\mathrm{SDi})$ & Worthy \\
$\mathrm{Mi}-1.5 \mathrm{SDDi})<\mathrm{X}<\mathrm{Mi}$ & Not feasible \\
$\mathrm{X}<\mathrm{Mi}-1.5(\mathrm{SDi})$ & Very unworthy \\
\hline
\end{tabular}

The ideal mean (Mi) and deviation deviation (SDi) were obtained using the formula as shown in figure 1.

$\mathrm{Mi}=1 / 2$ (highest score + lowest score)
$\mathrm{SDi}=16$ (highest score - lowest score)

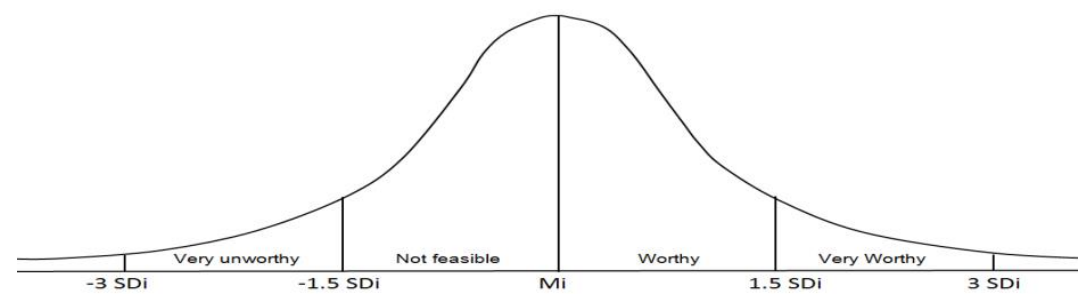

Figure 1. Normal Curve

The feasibility level assessment score in the table above will be used as a reference for test results by material experts, teachers and students. The score results obtained from the questionnaire will show the feasibility of the android application as a learning medium. 


\section{RESULTS AND DISCUSSIONS}

Data analysis was carried out to analyze the data from product trials through validation tests, alpha tests and beta tests. Analysis of the data from the validation test results by experts aims to determine the feasibility of learning media applications according to media experts and material experts. Analysis of the alpha test results data aims to determine the response to the assessment by the first user (teacher). While the beta test results data aims to determine the response to the assessment by end users (students).

1. Data Validation Test Results Needs Analysis

The data from the validation test results by media experts in the form of scores were converted into standard values with a score range of 0-100 (see Appendix 5). The assessment by media experts is assessed from 32 assessment indicators. The 32 points of the assessment consist of 15 points of aspects of the rules of learning media, 6 points of aspects of management and 11 points of aspects of CAI media. The following categories of assessments that have been converted into standard values can be seen in the table

Table 1.

Category Rating Scale 4 Media Experts

\begin{tabular}{cc}
\hline Score Interval & Category \\
\hline $75.00<\times 100.00$ & Very worth it \\
$50.00<\times 75.00$ & Worthy \\
$25.00<\times 50.00$ & Not feasible \\
$0.00<\times 25.00$ & Very unworthy \\
\hline
\end{tabular}

The data on the results of the media expert's assessment of the product based on the aspects of the rules of learning media, management and CAI media that have been converted can be seen in Table 13.

Table 2.

Media Expert Assessment Results Data

\begin{tabular}{lccccc}
\hline No & Validator & $\begin{array}{c}\text { Learning media } \\
\text { rules }\end{array}$ & Procedure & CAl media & Total score \\
\hline 1. & Media expert 1 & 57 & 24 & 43 & 124 \\
2. & Media expert 2 & 46 & 18 & 36 & 100 \\
\hline Average score & 51.50 & 21.00 & 39,50 & 112.00 \\
\hline Raw value conversion & 81.11 & 83.33 & 86.36 & 83.33 \\
\hline Category & Very worth it & Very worth it & Very worth it & Very worth it \\
\hline
\end{tabular}

From Table 13, it can be explained that the results of the assessment by media experts on the aspects of learning media rules obtained an average score of 51.50 . With this score, it can be interpreted that the learning media application is very feasible to use. Judging from the management aspect, the average score is 21.00 , with this score it can be interpreted that the application of learning media is very feasible to use. Judging from the CAI media aspect, an average score of 39.50 was obtained, with this score it can be interpreted that the application of the learning media is very feasible to use. Overall, the learning media application obtained a score of 112.00 with this score it can be interpreted that the learning media application is very feasible to use.

2. Data Validation Test Results from Material Experts

Data from the validation test results by media experts in the form of scores were converted into standard values with a score range of 0-100 (see Appendix 5). Assessment by material experts is assessed from 24 assessment indicator items. The 24 points of the assessment consist of 8 points of aspects of the rules of learning media, 6 points of aspects of 
management and 10 points of aspects of material relevance. The following assessment categories that have been converted into standard values can be seen in the following table:

Table 3.

Category Rating Scale 4 Material Expert

\begin{tabular}{cc}
\hline Score Interval & Category \\
\hline $75.00<\times 100.00$ & Very worth it \\
$50.00<\times 75.00$ & Worthy \\
$25.00<\times 50.00$ & Not feasible \\
$0.00<\times 25.00$ & Very unworthy \\
\hline
\end{tabular}

The data on the results of the material expert's assessment of the product based on the aspects of the rules of learning media, management and relevance of the converted material can be seen in Table 16.

Table 4.

Material Expert Assessment Results Data

\begin{tabular}{lccccc}
\hline No & Validator & $\begin{array}{c}\text { Media rules } \\
\text { Learning }\end{array}$ & Governance & $\begin{array}{c}\text { Material } \\
\text { relevance }\end{array}$ & $\begin{array}{c}\text { Total } \\
\text { score }\end{array}$ \\
\hline 1. & Material expert 1 & 25 & 19 & 30 & 74 \\
2. $\quad$ Material expert 2 & 26 & 21 & 30 & 77 \\
Average score & 25,50 & 20.00 & 30.00 & 75,50 \\
Raw value conversion & 72.92 & 77.78 & 66.67 & 71.53 \\
Category & Worthy & Very worth it & Worthy & Worthy \\
\hline
\end{tabular}

The data on the results of the teacher's assessment of the product based on the aspects of the rules of learning media, management, CAI media and the relevance of the converted material can be seen in Table 19.

Table 5.

Teacher Assessment Results Data

\begin{tabular}{|c|c|c|c|c|c|c|}
\hline No & Respondent & $\begin{array}{c}\text { Media rules } \\
\text { learning }\end{array}$ & $\begin{array}{c}\text { System } \\
\text { like }\end{array}$ & $\begin{array}{c}\text { Media } \\
\text { CAI }\end{array}$ & $\begin{array}{c}\text { Relevance } \\
\text { Theory }\end{array}$ & $\begin{array}{l}\text { Score } \\
\text { total }\end{array}$ \\
\hline 1. & Teacher 1 & 41 & 20 & 20 & 33 & 114 \\
\hline 2. & Teacher 2 & 42 & 22 & 18 & 35 & 117 \\
\hline 3. & Teacher 3 & 44 & 19 & 15 & 30 & 108 \\
\hline \multicolumn{2}{|c|}{ Average score } & 42.33 & 20.33 & 17.67 & 32.67 & 113.00 \\
\hline \multicolumn{2}{|c|}{ Raw value conversion } & 84.25 & 79.62 & 84.44 & 75.56 & 80.81 \\
\hline \multicolumn{2}{|c|}{ Category } & Very worth it & Veryworth & Veryworthy & Veryworthy & Veryworthy \\
\hline
\end{tabular}

From Table 19, it can be explained that the results of the assessment by the teacher on the aspects of the rules of learning media obtained an average score of 42.33. With this score, it can be interpreted that the learning media application is feasible to use. Judging from the management aspect, the average score is 20.33 , with this score it can be interpreted that the application of the learning media is very feasible to use. Judging from the CAI media aspect, an average score of 17.67 was obtained, with this score it can be interpreted that the application of the learning media is very feasible to use. Judging from the aspect of the relevance of the material obtained an average score of 32.67 with this score it can be interpreted that the application of learning media is very feasible to use. Overall learning media applications get a score of 113 ,

3. End User Test Results Data (Students)

Beta test results data by students in the form of scores are converted into standard values with a score range of 0-100 (see Appendix 5). Assessment by students is assessed from 23 
assessment indicator items. 23 The assessment points consist of 12 points of aspects of the rules of learning media, 5 points of aspects of CAI media and 6 items of material relevance aspects. The following categories of assessments that have been converted into standard values can be seen in the table

Table 6.

Rating Category 4 End User (Student) Scale

\begin{tabular}{cc}
\hline Score Interval & Category \\
\hline $75.00<\times 100.00$ & Very worth it \\
$50.00<\times 75.00$ & Worthy \\
$25.00<\times 50.00$ & Not feasible \\
$0.00<\times 25.00$ & Very unworthy \\
\hline
\end{tabular}

Data on the results of student assessments of products based on aspects of learning media rules, CAI media and the relevance of the converted material can be seen in Table:

Table 7.

Student Assessment Results Data

\begin{tabular}{|c|c|c|c|c|c|}
\hline No & Respondent & $\begin{array}{l}\text { Media rules } \\
\text { learning }\end{array}$ & $\begin{array}{c}\text { Media } \\
\text { CAI }\end{array}$ & $\begin{array}{c}\text { Relevance } \\
\text { Theory }\end{array}$ & Total score \\
\hline 1. & Student 1 & 46 & 18 & 24 & 88 \\
\hline 2. & Student 2 & 42 & 15 & 18 & 75 \\
\hline 3. & Student 3 & 37 & 15 & 18 & 70 \\
\hline 4. & Student 4 & 43 & 18 & 18 & 79 \\
\hline 5. & Student 5 & 39 & 16 & 18 & 73 \\
\hline 6. & Student 6 & 45 & 19 & 24 & 88 \\
\hline 7. & student 7 & 39 & 18 & 18 & 75 \\
\hline 8. & student 8 & 40 & 17 & 20 & 77 \\
\hline 9. & student 9 & 47 & 20 & 24 & 91 \\
\hline 10. & student 10 & 37 & 14 & 18 & 69 \\
\hline 11. & Student 11 & 37 & 17 & 18 & 72 \\
\hline 12. & student 12 & 33 & 13 & 17 & 63 \\
\hline 13. & student 13 & 42 & 17 & 18 & 77 \\
\hline 14. & Student 14 & 41 & 18 & 18 & 77 \\
\hline 15. & student 15 & 40 & 17 & 18 & 75 \\
\hline 16. & 16 student & 47 & 20 & 24 & 91 \\
\hline 17. & 17 student & 37 & 15 & 18 & 70 \\
\hline 18. & 18 student & 36 & 14 & 18 & 68 \\
\hline 19. & 19 student & 39 & 14 & 18 & 71 \\
\hline 20. & student 20 & 37 & 14 & 18 & 69 \\
\hline \multicolumn{2}{|c|}{ Average score } & 40,20 & 16.45 & 19.25 & 75,90 \\
\hline \multicolumn{2}{|c|}{ Raw value conversion } & 78.33 & 76.33 & 73.61 & 76.67 \\
\hline \multicolumn{2}{|c|}{ Category } & Very worth it & Very worth it & Worthy & Very worth it \\
\hline
\end{tabular}

From Table 22, it can be explained that the results of the assessment by students on the aspects of the rules of learning media obtained an average score of 40.20 . With this score, it can be interpreted that the learning media application is feasible to use. Judging from the CAI media aspect, an average score of 16.45 was obtained, with this score it can be interpreted that the application of the learning media is very feasible to use. Judging from the aspect of the relevance of the material obtained an average score of 19.25 with this score it can be interpreted that the application of learning media is feasible to use. Overall, the learning media application obtained a score of 75.90 with this score it can be interpreted that the learning media application is very feasible to use. 
The data in Table 22 is then compiled into a frequency distribution table as shown in Table

Table 8.

Frequency Distribution of End User Test Results

\begin{tabular}{lccc}
\hline \multicolumn{1}{c}{ Category } & Score & Frequency & Percentage (\%) \\
\hline Very worth it & $75.00<\times 100.00$ & 11 & 55 \\
Worthy & $50.00<\times 75.00$ & 9 & 45 \\
Not feasible & $25.00<\times 50.00$ & 0 & 0 \\
Very unworthy & $0.00<\times 25.00$ & 0 & 0 \\
Amount & & 20 & 100 \\
\hline
\end{tabular}

From Table 23 it can be seen that $55 \%$ of students in the beta test stated that the application of learning media was in the "very feasible" category as learning media. while $45 \%$ of students stated that the application of learning media was in the "appropriate" category to be used as learning media. There were no students who stated that the application of learning media was "inappropriate" or "very inappropriate" to use. With these results it can be interpreted that the application of learning media is very feasible to use.

\section{CONCLUSION}

Based on the research that has been done, it is known that $55 \%$ of students in the beta test stated that the application of learning media was in the "very feasible" category as learning media. while $45 \%$ of students stated that the application of learning media was in the "right" category to be used as learning media. There were no students who stated that the application of learning media was "inappropriate" or "very inappropriate" for use. These results are in accordance with the research conducted (Purbasari, 2013) which also concluded that the android application is feasible to be used as a learning medium.

\section{References}

Alfi, A. Faozan. (2002). Dasar Sistem Kendali (Bahan Ajar). Yogyakarta: Jurusan Pendidikan Teknik Elektro Fakultas Teknik UNY.

Alhuda, Jamaludin. (2010). Pengembangan dan implementasi media pembelajaran dot matriks berbasis mikrokontroler ATmega32nsebagai alat bantu praktikum pada kompetensi keahlian teknik elektronika industri di SMKN 2 Wonosari. FT UNY

Ally, Muhamed. (2009). Mobile learning: transforming the delivery of education and training. Québec: AU Press.

Arifin, Zainal. (2012). Penelitian Pendidikan Metode dan Paradigma Baru. Bandung: Rusda.

Arsyad, Azhar. (2002). Media Pembelajaran. Jakarta: Raja Grafindo.

Attewell, Jill., Savill-Smith, Carol. \& Douch, Rebecca. (2009). The impact of mobile learning Examining what it means for teaching and learning. London: LSA.

Azwar, Saifuddin. (2013). Reliabilitas dan validitas. Yogyakarta: Pustaka pelajar.

Chimbelu, Chiponda. (2014). Can tech help solve some of Africa's education problems?. Diakses dari http://www.de.de. 23 November 2021 pukul 13.33 WIB.

Cohen, Louis., Manion, Lawrence. \& Morrison, Keith. (2007). Research Method in Education Sixth edition. New York: Routledge.

Crowe, Judith A. (1996) Using Technology in Education. School of Education California Lutheran University. Diakses dari callutheran.edu pada tanggal 23 November 2021 pukul 13.33 WIB.

Darmawan, Deni. (2012). Teknologi Pembelajaran. Bandung: Remaja Rosdakarya.

Emzir. (2013). Metodologi Peneitian Pendidikan: Kualitatif dan Kuantitatif. Depok: Rafindo Pers.

Goldengekko. (2014). 10 Design Trends 2014 UX/UI trends for mobile solution. www.slideshare.net/goldengekko/mobile-apps-design-trends-2014 23 November 2021 pukul 13.33 WIB.

IDC. (2014). Smartphone OS Market Share, Q3 2013. Diakses dari http://www.idc.com/prodserv/smartphoneos-market-share.jsp 23 November 2021 pukul 13.33 WIB.

Istiyanto, Jazi Eko. (2013). Pemrograman Smartphone Menggunakan SDK Android dan Hacking Android. Yogyakarta: Graha IImu.

Lever-Duffy, Judy. McDonald, Jean B. (2009). Teaching and Learning With Technology. Boston: Pearson Education. 